\title{
Community-based Workshop to Strengthen the Role of Housewives in the Family (Case Study: Making Composter from Used Material)
}

\author{
Andi Prasetiyo Wibowo \\ \{andi.prasetiyo@uajy.ac.id\} \\ Universitas Atma Jaya Yogyakarta, Indonesia
}

\begin{abstract}
The family is an integral part of our education system. Starting from the family, a human will get the experience of getting his first information. It is essential for the role of the family in giving one's character. Without intending to discredit the role of women or in this case, homemakers in Indonesia, the figure was considered to be the spearhead of family education. The existence of information technology and social media makes it very easy for homemakers to get information, including establishing relationships with the outside world and finally forming a community. Including in efforts to preserve the environment, we should not underestimate the role of homemakers and trivial. A homemaker who performs activities at home and is identical to the kitchen, cooking and preparing food, is also able to create environmentally conscious movements that start from small things. Through community networks and supported by social media in this digital era, it is not hard to gather participants to engage in a workshop, in this case, to make a simple composter to convert household waste (food waste) into organic fertilizer. The making of the composter, made from a paint bucket and PVC pipe, is guided by a mentor who has made it previously. These housewives then go through the process of making the composter themselves, hoping they can better understand the process and be able to repeat it later. Interaction with the community/group also remains intertwined in the continued process afterwards. From this community, it is creating social relations to provide mutual support and maintain the spirit of environmental awareness.
\end{abstract}

Keywords: Women Empowerment, Social Media, Household-scale Composter, Waste Management, Used Material

\section{Introduction}

Indonesia, one of the largest countries in the world, is currently estimated to have a population of around 260 million. The composition of the male and female population in Indonesia tends to be balanced. However, based on data from the Central Statistics Agency, the population of women compared to men is still more than 131 million compared to 130 million [1]. Of this, approximately $67 \%$ are in the productive age, which makes Indonesia expected to reach the peak of "demographic bonus" in 2017 - 2019 in the first wave and 2020 - 2030 in the second demographic bonus wave [2]. This situation indeed becomes a challenge in the development and empowerment of human resources. 
Education, as part of the process providing education and human thought processes, is a concern and responsibility for many parties, not just depending on the government. The education referred to her includes formal academic education, and also includes education about behaving and behaving to others and the environment. One of the interesting things is that the development of social intelligence is also greatly influenced by mother's upbringing and encouragement, the extent of the success of mother's upbringing is the extent of the involvement and role of mothers in the lives of their children [3].

The role of mothers, or in this case, women, is often ignored given the strong patriarchal culture in Indonesia. Not only in Indonesia, in a study conducted by Hatice Bekir et al. (2014), it revealed that there are still many assumptions that the role of women in the family is not worthy of being considered equal to men [4]. The highest educational opportunity that makes women able to control their goals and change their roles as wives and mothers are still unacceptable to most people [5]. Satrio, in his thesis, said that women in the process of looking for work tend to find jobs more easily than men [6]. However, unfortunately, women who then have to work outside the home often get an extra burden morally [7]. The existence of policies, facilities and programs made by companies and governments to support women workers so that they can continue to play a dual role without having to experience role conflict, is a very significant form of social support [8]. Patriarchal culture, a culture of male domination over women, is accused of being one of the main factors influencing women's dual burden. This patriarchal culture has even emerged in religious understanding so that when a woman is negligent about her responsibilities in the domestic sphere, she will be justified as violating religious orders (Islam). This double burden is a form of gender injustice which in this context is women workers. Whereas for women who do not work [9] in the end are only considered as citizens of the 2nd class, because there is an assumption or assumption that housewives are considered as unemployed. The housewives are always identified with domestic work such as washing, cooking, caring for children and others. In this condition, the connection with the outside of the house will certainly become increasingly limited if it is not supported by access to technology-based information such as the internet.

The internet is becoming an inseparable part of our lives today. The emergence of social media, in addition to self-actualization, can also be used as a means to discuss and provide information and establish communication without being limited by distance and time. Digital communication cannot replace the impression of a physical meeting, but through the digital communication media, it can be used to coordinate, for example, to hold a meeting. Publication through social media or other forms of digital communication such as WhatsApp Group is believed to be able to reach more people. The use of the internet as a source of information can also provide many conveniences; for example, we can easily find a guide to making composter independently. Following the guidelines can sometimes be successful. Sometimes, there are also some that are actually confusing. In this case, trying directly and the role of physical assistance is also irreplaceable. The workshop is expected to be an effective learning medium.

\section{Research Method}

The assistance and empowerment of women are carried out through a workshop. In this case, the workshop that was conducted was making composter by utilizing used goods. The making is done together, but the participants are actively involved in each stage. This is 
intended so that the level of understanding of the workshop material can be better and be able to create a sense of more ownership of the objects produced. The publication system for getting workshop participants is done through social media Instagram, and subsequently, the post-workshop facilitation system is carried out using social media (WA groups) to accommodate questions and discussions and share other information.

\section{Result and Discussion}

This section will discuss organic waste generated from housewives' activities that deal with kitchen activities on a daily basis. The waste can then be processed into fertilizer through composter. This manufacturing process can be studied and practiced independently. Mentoring and workshop activities are also expected to be able to provide more roles for women so that they do not only play a role as housewives who are identical to domestic work.

\subsection{Household Waste Management}

Households that produce domestic waste every day will have a bad impact if not managed properly. The amount of waste generated from households may be nothing compared to waste generated from other sectors. However, the collective amount of garbage produced by this household will certainly make the condition of the landfill site become full of waste quickly, especially the more limited capacity. If it is assumed that every house process and makes food for daily consumption, the waste generated from these household activities will be mostly in the form of leftover vegetables and fruit which is a type of organic waste. This type of waste can actually be processed into fertilizer. The fertilizer is then referred to as organic fertilizer. Many studies reveal the many benefits of organic fertilizer for nature. There are many techniques in the process of making organic fertilizer, one of which is through composter as a medium for making household liquid organic fertilizer.

\subsection{Workshop on Making a Household-Scale Composter}

This activity was started by creating an announcement and an invitation to be involved in the composter-making workshop. This activity is part of a community movement in Yogyakarta that cares about the environment. The implementation of community-based workshops such as this has actually been widely applied elsewhere in foreign countries with various fields, and types of communities [10][11][12] and is quite effective. Information about the workshop was disseminated using social media facilities in the form of Instagram, which was then easily disseminated among the community but did not rule out the possibility of involving participants outside the existing community. The workshop was held for one day for approximately 3-4 hours, starting at 9 in the morning and ending at approximately 1 o'clock in the afternoon. 


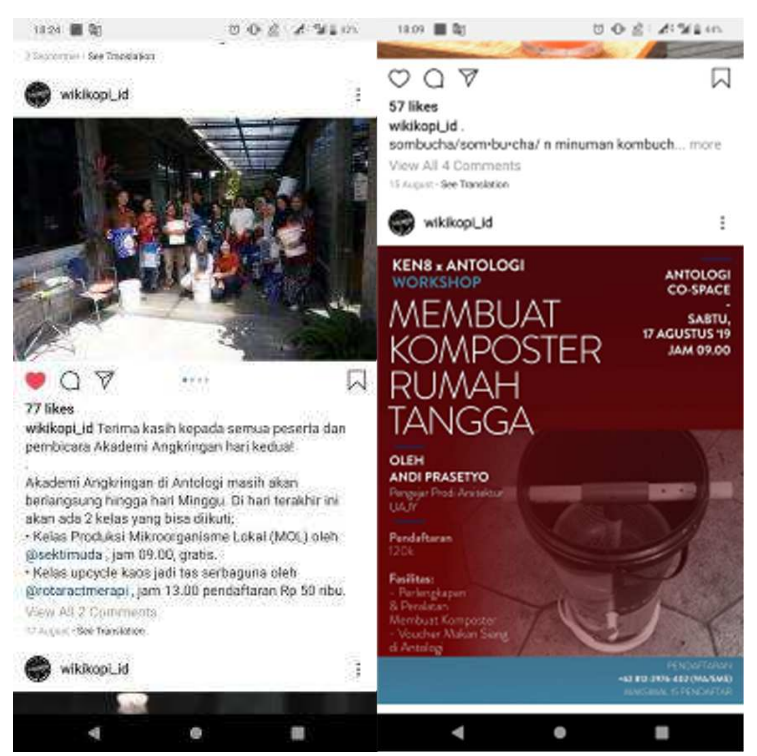

Fig. 1. Publication using Instagram.

The workshop began with a brief description of the technical implementation and explanation of the tools and materials to be used. The materials that are used in this workshop mostly used materials. One of the main things is to use the used paint bucket as a container/composter.

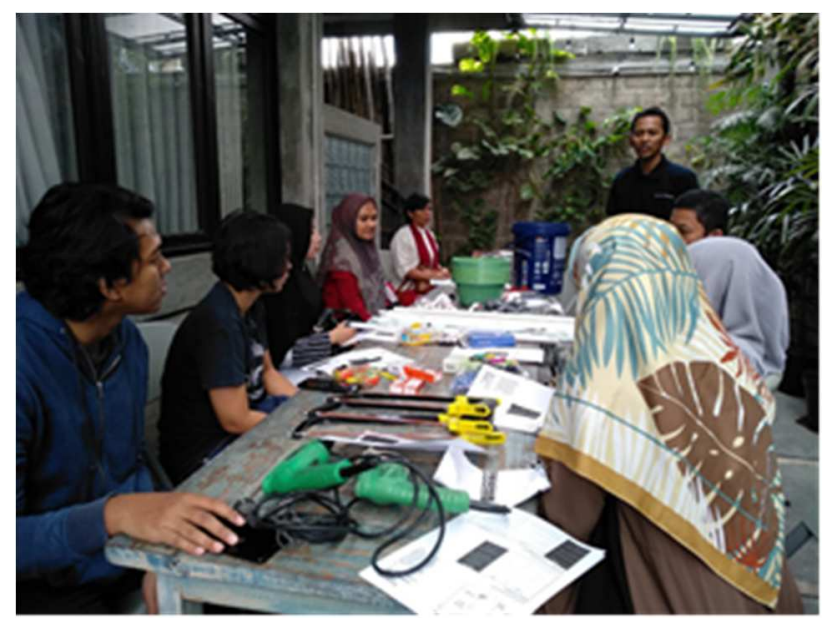

Fig. 2. Briefing. 
Table 1. Tools and Materials

\begin{tabular}{|l|l|}
\hline \multicolumn{1}{|c|}{ Tools } & \multicolumn{1}{c|}{ Materials } \\
\hline Measuring tape & Used plastic paint bucket (1 pail) \\
markers & Used pipe 1 " $(80 \mathrm{~cm})$ \\
large cutter & (pipe accessories) T - size 1 " \\
candles + lighters & round plastic basket d.30cm \\
hot glue gun & plastic dispenser faucet \\
hot glue gun & gauze (can also be plastic strimin) \\
hacksaw & clear tape \\
drill + drill bit size $4 "$ & \\
\hline
\end{tabular}

The workshop participants totaled 12 people and were dominated by women. From the monitoring process during the implementation, these women, who were found to be housewives, were quite actively involved in the process of making composter. These women are not awkward when doing some work that is identical to the work of men such as sawing, making holes by using an electric drill, and so forth. They were quite enthusiastic in participating in the activity; some of them even said it was their first time holding a tool called a saw and an electric drill.

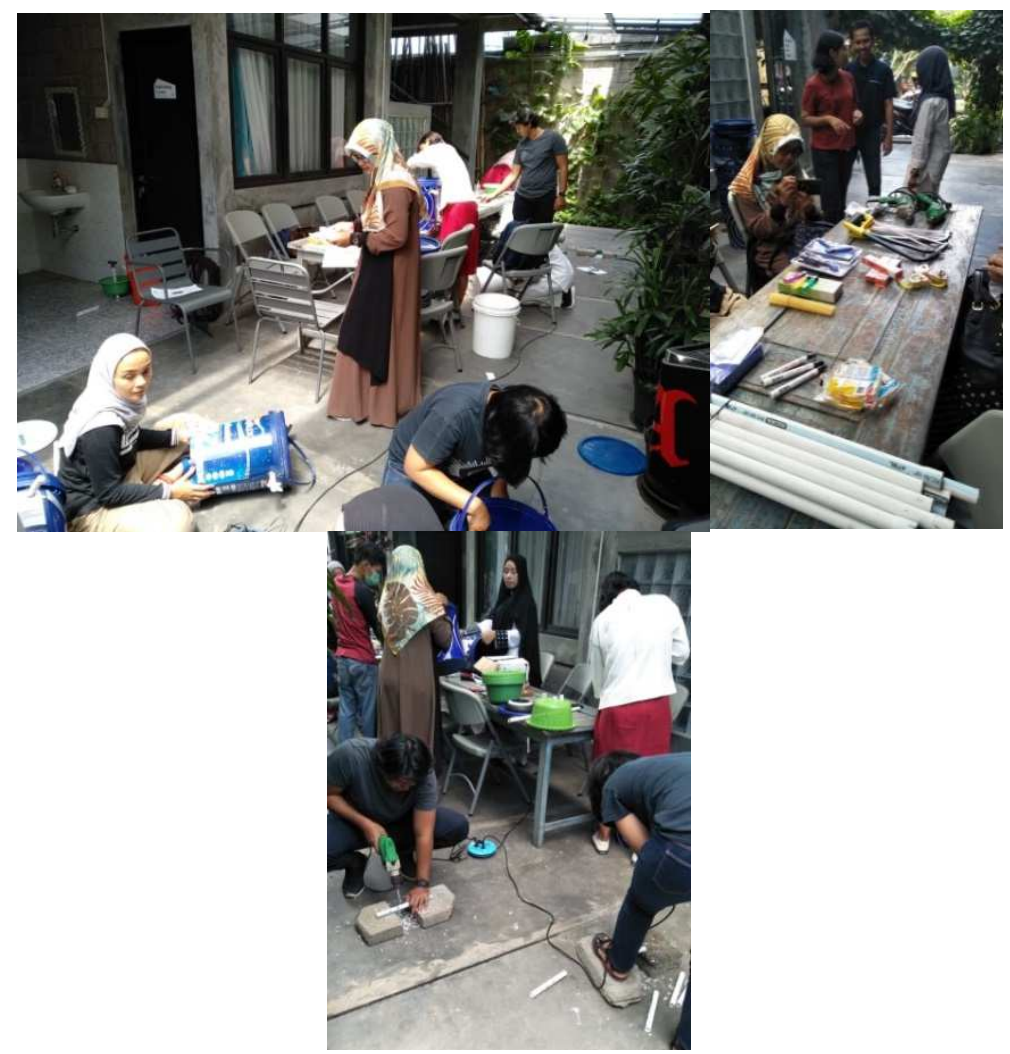

Fig. 3. The process of making Composter. 


\subsection{Post-Workshop Community}

After the workshop, the participants then took the initiative to create a discussion group with a view to sharing information. Utilization of WhatsApp (WA) group is considered to be the best solution because all participants have contact numbers connected to the WA application. In the group, the contact numbers of the workshop speakers were also included to provide direction and answer questions from the participants. The participants were enthusiastic in the discussion and shared information about the process of processing waste into organic fertilizer to show the results/impact on plants that were given the results of the composter fertilizer. Through the WA group, the participants also shared information about other similar activities and other follow-up activities.

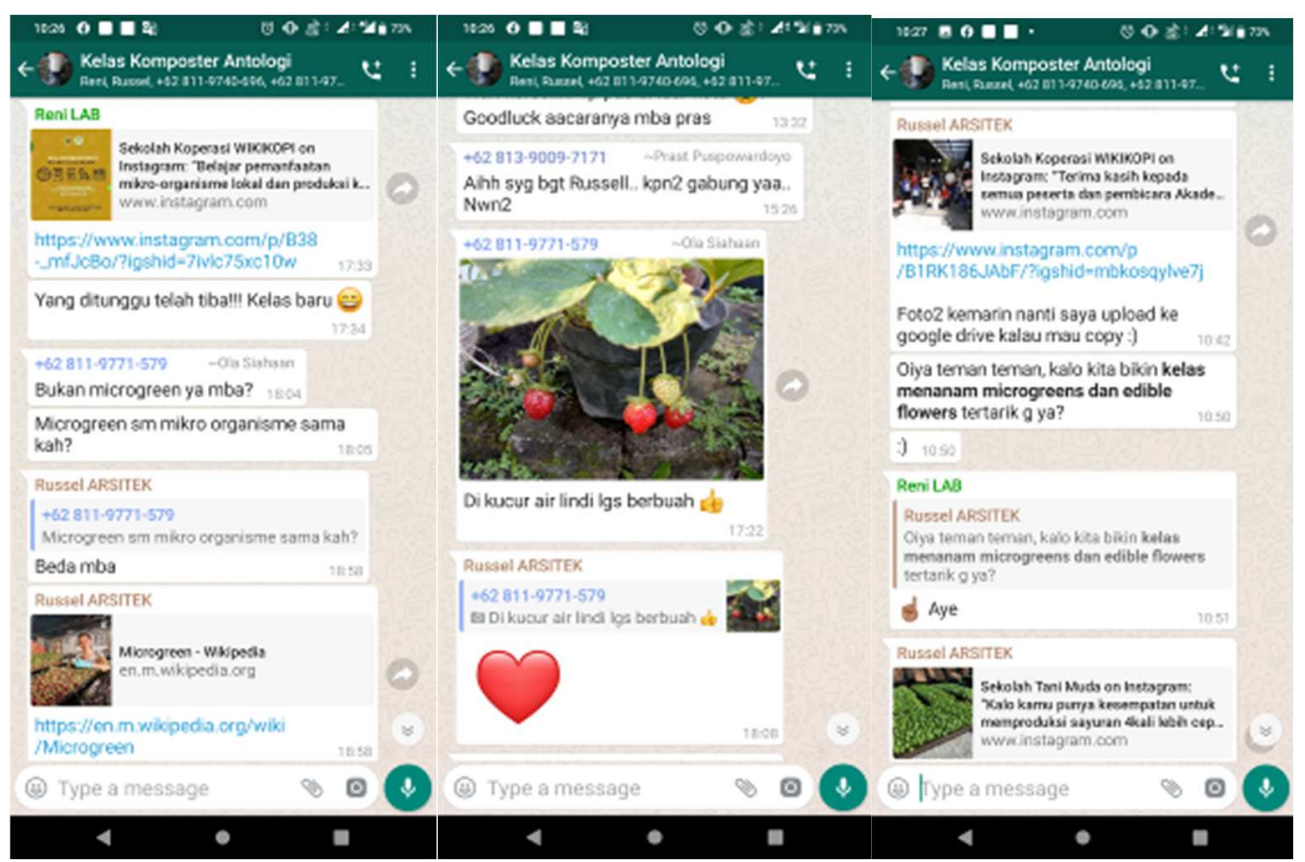

Fig. 4. Sharing and Discussion Through WA Group.

\section{Conclusion}

Women especially housewives, if given the opportunity and trained, can also have abilities that are not inferior to men. Basically, all humans are the same, but with the urge to try something new and the enthusiasm to be able to do something more, the housewives are able to be encouraged to be able to do something that not only can be done by men. at first, it would be difficult and housewives would feel awkward doing work that is identical to men. However, this only takes time and habituation so that later it will create a condition where it is considered reasonable. Jobs that have been claimed can only be done by men, maybe, in the end, can also be done by women.

Social media, if properly utilized, can be a means of sharing positive information. The community formed from associations on social media was effective enough to establish 
communication and discussion. Social media is a place to gather and share information without the limitations of distance and time. Indeed, there are still many who doubt the effectiveness of this social media, such as we do not really know who wrote and disseminated information. But with the existence of associations/groups, where there are user control and the inclusion of group members who join, this worrying thing can be ignored. We can be sure that the people who belong to the group are part of the group that we can be sure of.

With a little creativity, used goods can be used as something useful. From this article, we can learn that the concept of recycling can be applied in making composts by using a used paint-bucket. In the process of making the composter, there are indeed some other materials that are categorized as new items, but this is at least a small part of the spirit to reduce waste and turn it into something more useful. Creativity is needed to create an item that suits our needs. Sometimes we cannot fully use and apply the ideas of others before, there need to be adjustments to the conditions that we are currently facing.

Organic fertilizers produced from simple composter products can have a positive impact. Many composter makers who have used their composter to process household waste into liquid fertilizer give the testimonials as evidence. Some workshop participants showed that plants that were given liquid fertilizer could grow well. The effect of water fertilizer is indeed the existence of unpleasant odors. But, with special treatment, the unpleasant odor can be minimized so that it does not disturb the surrounding environment.

\section{References}

[1] BPS, Perempuan dan Laki-laki di Indonesia. 2017.

[2] W. R. Jati, "Bonus Demografi sebagai Mesin Pertumbuhan Ekonomi: Jendela Peluang atau Jendela Bencana di Indonesia?," Populasi, vol. 23, no. 1, pp. 1-19, 2015.

[3] R. Robbiyah, D. Ekasari, and R. Witarsa, "Pengaruh Pola Asuh Ibu terhadap Kecerdasan Sosial Anak Usia Dini di TK Kenanga Kabupaten Bandung Barat," J. Obs. J. Pendidik. Anak Usia Dini, vol. 2, no. 1, pp. 76-84, 2018.

[4] H. Bekir, H. Şahin, and R. Aydin, "University Students' Perception on Woman's Place in a Family," Procedia-Social Behav. Sci., vol. 143, pp. 14-18, 2014.

[5] N. Angelia, "Analisis Status Perempuan dan Kematian Ibu," Publikauma J. Adm. Publik Univ. Medan Area, vol. 2, no. 1, pp. 31-39, 2014.

[6] S. A. Setiawan and N. Woyanti, "Pengaruh umur, pendidikan, pendapatan, pengalaman kerja dan jenis kelamin terhadap lama mencari kerja bagi tenaga kerja terdidik di kota Magelang." Universitas Diponegoro, 2010.

[7] N. Hidayati, "Beban ganda perempuan bekerja (antara domestik dan publik)," J. Muwazah, vol. 7, no. 2, pp. 108-109, 2015.

[8] D. Rosiana, "Mengatasi Konflik Peran Sebagai Karyawan dan Ibu Rumah Tangga Pada Tenaga Kerja Wanita di Indonesia," Mimb. J. Sos. dan Pembang., vol. 23, no. 2, pp. 271-287, 2007.

[9] H. Junaidi, "Ibu Rumah Tangga: Streotype Perempuan Pengangguran," An Nisa'a, vol. 12, no. 1, pp. 77-88, 2017.

[10] X. Dong, Y. Li, R. Chen, E.-S. Chang, and M. Simon, "Evaluation of community health education workshops among Chinese older adults in Chicago: A community-based participatory research approach," J. Educ. Train. Stud., vol. 1, no. 1, pp. 170-181, 2013.

[11] R. Thomas, W. Gifford, and C. Hammond, "Writing toward well-being: A qualitative study of community-based workshops with breast cancer survivors," Can. Oncol. Nurs. J., vol. 27, no. 2, p. 178, 2017.

[12] P. Bronowski, M. Sawicka, M. Rowicka, and M. Jarmakowicz, "Social networks and social functioning level among occupational therapy workshops and community-based support centers users," Psychiatr. Pol., vol. 51, pp. 139-152, 2017. 